\title{
Plasmid DNA/RNA separation by ultrafiltration: Modeling and application study
}

\author{
José C. Nunes ${ }^{\mathrm{a}}$, Maria Teresa Pessoa de Amorim ${ }^{\mathrm{b}}$, Isabel C. Escobar ${ }^{\mathrm{c}}$, João A. Queiroz ${ }^{\mathrm{a}}$, \\ António M. Morão ${ }^{\text {a,* }}$ \\ ${ }^{a}$ Centro de Investigação em Ciências da Saúde, University of Beira Interior, 6201-001 Covilhã, Portugal \\ ${ }^{\mathrm{b}}$ Department of Textile Engineering, University of Minho, 4800-058 Guimarães, Portugal \\ ${ }^{\mathrm{c}}$ Department of Chemical and Environmental Engineering, University of Toledo, Toledo, $\mathrm{OH} 43606$, USA
}

\section{A R T I C L E I N F O}

\section{Article history:}

Received 9 October 2013

Received in revised form

12 March 2014

Accepted 13 March 2014

Available online 20 March 2014

\section{Keywords:}

Plasmid DNA

Ultrafiltration

Modeling

RNA

\begin{abstract}
A B S T R A C T
RNA is one of the main soluble contaminants that needs to be separated from plasmid DNA (pDNA) during its recovery process from fermentation broths. Although significantly different in molecular size, pDNA and RNA are difficult to separate by membrane filtration due to the fact that both types of molecules are highly deformable and therefore suffer flow-induced elongation when permeating through porous membranes. The possibility of performing this separation by ultrafiltration is investigated here with the aid of a theoretical model describing the interactions between two electrically charged, flexible macromolecules that simultaneously permeate through a porous membrane. The results of the simulations, applied to pDNA and the different types of RNA present in cell lysates under typical process conditions, show that only by a careful choice of the membrane pore size and the imposed permeate flux one can achieve the required selectivity in this operation. Ultrafiltration tests using microfiltered lysates from the production of two different plasmids, pVAX1-LacZ (6050 bp) and pCAMBIA-1303 (12,361 bp), were carried out to check the validity of the theoretical predictions; the experimental results confirm these predictions and the idea that this technique can be used in practice for pDNA purification.
\end{abstract}

(c) 2014 Elsevier B.V. All rights reserved.

\section{Introduction}

In the past decade, a significant research has been carried out in the field of plasmid DNA (pDNA) recovery from fermentation broths, aiming at its large-scale production for applications in gene therapy and the production of DNA vaccines [1-3]. Membranebased separation technologies are present in almost all biotechnology fields, for a wide variety of applications [4,5].

The recovery of pDNA from fermentation broths, which can be carried out by different techniques, typically involves a cell lysis step followed by solid-liquid separation, subsequent precipitation of the pDNA with alcohols such as ethanol or isopropanol (or other precipitating agents), re-suspension of the pDNA concentrate and its purification from RNA and other contaminants by adsorption techniques, typically by chromatography. Chromatographic techniques are generally required to isolate the supercoiled isoform of plasmid DNA, pDNA(sc), with the required quality standards that are imposed by regulatory agencies for the final product, such as

\footnotetext{
* Corresponding author.

E-mail address: ammorao@ubi.pt (A.M. Morão).
}

the U.S. Food and Drug Administration and the EMEA (European Agency for the Evaluation of Medical Products) [1,2,6]. Membrane filtration has been successfully used to perform cell harvest from fermentation broths in this type of processes and similar ones involving cell suspensions [1,10-12] and also for the selective retention of cell debris after cell lysis while allowing the permeation of pDNA [7-9]. Also, it has been shown to be adequate for concentration of pDNA with simultaneous buffer exchange and small ion removal after chromatographic purification and also for sterilization of the final product $[1,13,14]$. Besides these applications, membrane filtration can also be considered for pre-purification and concentration of the pDNA before chromatography, as an alternative to the use of organic solvents or other precipitating agents.

The application of ultrafiltration to purify pDNA from RNA and other contaminants has been studied by different independent authors. Kendall et al. [15] studied the purification of pDNA by adsorption in a nitrocellulose membrane, after a microfiltration step; this offers the possibility of almost completely removing RNA, genomic DNA and other hydrophobic contaminants from the solution, before chromatography; however, the fouling-related issues and the limited capacity of the membranes to work as absorbers may be serious drawbacks for the practical application 
of that technique. Eon-Duval et al. [16] added calcium chloride to the lysates and subsequently performed a microfiltration, to achieve an almost complete removal of RNA and the removal of the cell debris from the alkaline lysis step, in one single filtration operation. The fact that large quantities of the precipitating agent must be used in practice is a disadvantage of this method. Kahn et al. [17] studied the ultrafiltration of different plasmids to achieve pDNA concentration and purification from RNA after a modified alkaline cell lysis procedure developed by the authors and subsequent removal of suspended solids by dead-end filtration; this method involved the degradation of RNA molecules by increasing the incubation time up to $24 \mathrm{~h}$ during the alkaline lysis step, before neutralization. That technique has the disadvantage that only for long incubation times purification is achieved and it is not clear that the pDNA is not significantly degraded under these conditions. More recently, Nunes et al. [8] studied the application of a microfiltration membrane to perform the solidliquid separation immediately after cell lysis and, subsequently, an ultrafiltration membrane was tested to concentrate and pre-purify the pDNA before chromatography. The results were promising since high yields of pDNA recovery were obtained, however, the purification degree, namely, in terms of high molecular weight RNA (HMwRNA) removal was modest.

Following from that recent study, it was investigated here the optimization of the ultrafiltration operation in order to improve the separation between pDNA and HMwRNA. The effects of the main parameters controlling the separation, namely, the membrane pore radius and the permeate flux were studied on both a theoretical and an experimental basis. The previously developed model for the permeation of flexible macromolecules in membranes with narrow pores in 3-component systems (one macromolecule plus two inorganic ions, i.e., the salt) $[3,8,18]$ was extended to 4-component systems, i.e., two macromolecules plus the salt. Under this approach the interactions between pDNA and the RNA molecules in the concentration polarization layer were taken into account for the first time and the resulting effects on the sieving coefficients of these species were investigated. The new numerical algorithm allowed the optimization of the filtration conditions before the experiment. Then, the purification of two different plasmids, pVAX1-lacZ and pCAMBIA-1303, with $6050 \mathrm{bp}$ and $12,361 \mathrm{bp}$, respectively, was carried out experimentally to check the validity of the theoretical predictions.

\section{Materials and methods}

\subsection{Plasmid production and cell lysis}

E. coli DH5 $\alpha$ cells, containing a 6050 bp plasmid ( $p$ VAX1-lacZ), and E. coli XL1blue cells containing a 12,361 bp plasmid ( $p$ CAMBIA1303) were cultivated, using the same cell growth conditions as described in [19]. pVAX1-lacZ containing cells were cultivated in terrific broth medium (12 g/L triptone (Sigma), $24 \mathrm{~g} / \mathrm{L}$ yeast extract (Fluka), $4 \mathrm{~mL} / \mathrm{L}$ glycerol (Himedia), $0.017 \mathrm{M} \mathrm{KH}_{2} \mathrm{PO}_{4}$ (Panreac) and $0.072 \mathrm{M} \mathrm{K}_{2} \mathrm{HPO}_{4}$ (Panreac)), and pCAMBIA containing cells were produced in Luria Bertani medium (10 g/L triptone, $5 \mathrm{~g} / \mathrm{L}$ yeast extract, $10 \mathrm{~g} / \mathrm{L} \mathrm{NaCl}$ (Panreac), pH 7.0). Cell lysis is achieved by a modification of the alkaline lysis method, originally developed by Birnboim and Doly [20]. Briefly, $4 \mathrm{~mL}$ of $0.2 \mathrm{M} \mathrm{NaOH}$ (Panreac) and $1 \%$ SDS (Himedia) solution were added to $4 \mathrm{~mL}$ of a $120 \mathrm{~g} / \mathrm{L}$ (wet weight) cell suspension in $\mathrm{T}_{50} \mathrm{E}_{10}$ buffer $(50 \mathrm{mM}$ Tris (Fischer BioReagents) and $10 \mathrm{mM}$ EDTA (Sigma), pH 8.0). After 5 min of incubation at room temperature, $4 \mathrm{~mL}$ of a pre-chilled $\left(4^{\circ} \mathrm{C}\right) 3 \mathrm{M}$ potassium acetate (Sigma-Aldrich ReagentPlus) solution at $\mathrm{pH}=5.0$, with the $\mathrm{pH}$ adjusted with acetic acid (Panreac), were then added to the lysate, and the final suspension was kept on ice for $15 \mathrm{~min}$ before further processing.

\subsection{Processing of cell lysates - microfiltration}

The alkaline lysate, containing a large quantity of suspended solids, was processed by microfiltration, using a hydrophilic nylon microfiltration membrane (Nylaflo, Pall), with a nomimal pore diameter of $0.2 \mu \mathrm{m}$. A continuous diafiltration was performed in a $50 \mathrm{~mL}$ stirred cell (model 8050, Millipore) with the stirrer speed adjusted to $100 \mathrm{rpm}$. The permeate flow was set at $1 \mathrm{~mL} / \mathrm{min}$ by a peristaltic pump (403U/VM2, Watson Marlow) placed after the membrane (thus working by suction). The volume of lysate processed in each run was $10 \mathrm{~mL}$. The volume of the cell suspension was kept constant by continuous addition of Tris/ $\mathrm{HCl} 10 \mathrm{mM}$ buffer at $\mathrm{pH}=8.0$ (Tris buffer) which was fed to the cell using a second peristaltic pump (101U/R, Watson Marlow) throughout the diafiltration. The procedure was completed after collecting $30 \mathrm{~mL}$ of permeate. A theoretical pDNA recovery yield of approximately $95 \%$ in the permeate was expected, considering total permeation of the plasmid.

\subsection{Ultrafiltration}

Ultrafiltration experiments were carried out in a $10 \mathrm{~mL}$ stirred cell (model 8010, Millipore). In all the experiments the initial volume of microfiltered alkaline lysate was $10 \mathrm{~mL}$ and $9 \mathrm{~mL}$ of permeate were collected, which gives a volumetric concentration factor $(V C F)$ of 10 . Two different membranes were tested: $100 \mathrm{kDa}$ NMWCO membrane in fluoro polymer (FS40PP, DSS/Alfa-Laval) and a $300 \mathrm{kDa}$ NMWCO polyethersulfone membrane (Biomax 300, Millipore). The indicated NMWCO values are given by the manufacturers. These membranes were previously characterized in terms of pore dimensions using the symmetrical pore model (SPM) developed by Morão et al. [21]. The permeate flow was kept constant using a peristaltic pump (101U/R, Watson Marlow) placed after the membrane and the stirring speed was set at 100 or $760 \mathrm{~min}^{-1}$ (1.67 or $12.7 \mathrm{~s}^{-1}$ )(previous calibration was performed).

\subsection{Analytical}

\subsubsection{Plasmid DNA assay}

Plasmid DNA was quantified by HIC using the method developed by Diogo et al. [22]. A HIC Source 15 PHE column from Amersham Biosciences (GE Healthcare) was connected to a Äkta purifier FPLC system (GE Healthcare). The column was initially equilibrated with $1.5 \mathrm{M}\left(\mathrm{NH}_{4}\right)_{2} \mathrm{SO}_{4}$ in Tris buffer. Samples of $20 \mu \mathrm{L}$ were injected and eluted at a constant flow rate of $1 \mathrm{~mL} / \mathrm{min}$. 2 min after injection, the eluent was instantly changed to Tris buffer in order to elute bound species. This concentration was maintained for $4 \mathrm{~min}$ before re-equilibration of the column in order to prepare it for the next run. The absorbance of the eluate was recorded at $260 \mathrm{~nm}$. The concentration of pDNA in each sample was calculated from a calibration curve; the pDNA standards were obtained using a commercial purification kit (Maxi kit, Qiagen). This method was studied in detail in a previous work [8], where it was proposed that it can also be used to estimate the total RNA concentration in the samples.

\subsubsection{Agarose gel electrophoresis}

Samples were analyzed by horizontal electrophoresis in $1.0 \%$ agarose (Grisp) gels prepared in TAE buffer ( $40 \mathrm{mM}$ Tris, $20 \mathrm{mM}$ acetic acid and 1 mM EDTA, pH 8.0), supplemented with GreenSafe stain (NZYTech). Electrophoresis was carried out at $110 \mathrm{~V}$ for $40 \mathrm{~min}$, in TAE buffer, in a BioRad cell. The gels were visualized 
Table 1

Main components of the microfiltration permeates and their relevant properties for modeling purposes.

\begin{tabular}{|c|c|c|c|c|c|}
\hline Compound & $C_{b} /\left(\mathrm{mol} \mathrm{m}^{-3}\right)$ & $M w / \mathrm{Da}$ & $r_{s} \times 10^{9} / \mathrm{m}$ & $r_{\mathrm{g}} \times 10^{9} / \mathrm{m}$ & $D /\left(\mathrm{m}^{2} \mathrm{~s}^{-1}\right)$ \\
\hline $\mathrm{CH}_{3} \mathrm{COO}^{-}$ & 317 & 59 & 0.227 & - & $1.089 \times 10^{-9}$ \\
\hline $\mathrm{K}^{+}$ & 317 & 39 & 0.125 & - & $1.95 \times 10^{-9}$ \\
\hline 5S RNA & $\begin{array}{l}2.26 \times 10^{-3 a} \\
8.45 \times 10^{-4 b}\end{array}$ & 40,800 & 3.39 & 5.10 & $7.29 \times 10^{-11}[8]$ \\
\hline 16S RNA & $\begin{array}{l}1.06 \times 10^{-4 a} \\
8.99 \times 10^{-5 b}\end{array}$ & 523,940 & 13.6 & 20.5 & $1.82 \times 10^{-11}[8]$ \\
\hline 23S RNA & $\begin{array}{l}5.63 \times 10^{-5 a} \\
4.77 \times 10^{-5 b}\end{array}$ & 987,360 & 17.8 & 26.8 & $1.39 \times 10^{-11}[8]$ \\
\hline pDNA & $\begin{array}{l}4.47 \times 10^{-6 a} \\
6.39 \times 10^{-7 b}\end{array}$ & $\begin{array}{l}3.99 \times 10^{6} \\
8.16 \times 10^{6}\end{array}$ & $\begin{array}{c}83.1 \\
134\end{array}$ & $\begin{array}{l}87.3 \\
138.7\end{array}$ & $\begin{array}{l}2.97 \times 10^{-12}[23] \\
1.85 \times 10^{-12}[23]\end{array}$ \\
\hline
\end{tabular}

a Lysates from $p V A X-L a c Z 1$ production.

${ }^{\mathrm{b}}$ Lysates from $P$ CAMBIA production.

in an Essential V2 transilluminator from Uvitec. To concentrate, and/or to avoid salt interferences, some samples were desalted using the 2-Propanol precipitation method described in [8].

\subsubsection{Protein assay}

Total protein concentration in the samples was measured using a Pierce micro-BSA assay (Thermo Scientific), as described in [6]. Briefly, $50 \mu \mathrm{L}$ of the sample were mixed with $200 \mu \mathrm{L}$ of BCA reagent in 96well microplate and then incubated for $30 \mathrm{~min}$ at $60{ }^{\circ} \mathrm{C}$. The plate was cooled to room temperature for another $15 \mathrm{~min}$ and then the absorbance was measured at $595 \mathrm{~nm}$ in a microplate reader. Calibration curves were prepared with BSA (Sigma) standards in the range of $25-500 \mu \mathrm{g} / \mathrm{mL}$. To avoid salt interferences, the samples were previously desalted by size-exclusion chromatography in $P D-10$ columns (Amersham Biosciences, GE Healthcare), according to the manufacturer's instructions, using $\mathrm{NaCl} 0.15 \mathrm{M}$ in Tris Buffer as eluent.

\subsection{Simulations}

In order to optimize the ultrafiltration operation to simultaneously obtain high pDNA retention and high RNA permeation, simulations were carried out herein for 3-component systems containing the macromolecule of interest (pDNA or RNA, as component 1), acetate ion (component 2) and potassium ion (component 3) using the computational method described in $[3,8]$, and for 4-component systems containing the plasmid, an RNA species (23S, 16S or 5S RNA), an acetate ion and a potassium ion. Although there are other ions present in the solution, $\mathrm{CH}_{3} \mathrm{COO}^{-}$and $\mathrm{K}^{+}$arising from the alkaline lysis procedure are, by far, the main ionic species in the solution, being the main responsible for the electric charge screening effects that strongly affect the concentration polarization of the macrosolutes (pDNA and RNA, that are highly charged molecules) [3,8].

The previously developed mass transfer model allows the estimation of sieving coefficients of macrosolutes in membranes with narrow pores, i.e., with an average pore diameter smaller than the radius of gyration of the macrosolute, which only needs to have a flexible structure. The model was originally developed for linear macromolecules that could be modeled as freely jointed chains (FJC), namely, linear DNA and linear polysaccharides [23]; subsequently it was extended to the case of closed segmented chains (CSCs) [3]. In fact, it was found that the same equation which relates the radius of gyration of a flexible macromolecule and the membrane pore radius with the partition coefficient of that macromolecule between the solution and the pore, applies either in the case of a FJC or a CSC [3]. Although a pDNA molecule can be modeled as a FJC, the CSC representation is, apparently, a better approach in order to obtain more realistic values of the gyration radius [3]. This same model can also be used for predicting RNA permeation, considering the RNA species as linear macromolecules, i.e., using the FJC approach, as recently shown by Nunes et al. [8]; the authors applied the 3-component model to predict the permeation of the main different types of RNA present in the lysates, i.e., 23S RNA, 16S RNA and 5S RNA individually.

The possible mutual interference between RNA and pDNA on their simultaneous permeation is investigated here for the first time, by considering 4-component systems. This represents a considerable improvement of our previous approach $[3,8]$. The inclusion of more components in the system would be desirable but it considerably increases the complexity of the numerical calculations and the time needed for the computational process. Besides this, as it will be shown later, the most important interference is the effect of the pDNA present in the sieving coefficients of the RNA species and not the opposite (and this effect can be estimated using the 4-component approach). The main details about the new algorithm used for the calculation of sieving coefficients are given in Appendix A.

Simulations of the ultrafiltration process were carried out by considering a typical batch filtration set-up performed in a stirred cell, using $10 \mathrm{ml}$ of initial solution (microfiltration permeate), operated under conditions of constant permeate flux and constant stirring speed, in concentration mode, consistent with the experimental procedure described in Section 2.3. The model of the stirred cell used, an Amicon 8010 from Millipore, is relevant for the estimation of the thickness of the concentration polarization layer, $\delta$ [3]. The initial concentrations of the macromolecules and salts used for the simulations and their relevant properties for this study are indicated in Table 1.

Stokes radii, $r_{s}$, were estimated from the diffusion coefficients, $D$, using the Stokes-Einstein equation, which were obtained from the literature, assuming infinite dilution. Gyration radii, $r_{g}$, of the plasmids were estimated using the CSC approach [8] for an ionic strength of $317 \mathrm{~mol} \mathrm{~m}^{-3}$. For the RNA species the indicated values of $r_{g}$ were estimated from the corresponding Stokes radii, as described in [8]. Further details about the simulation of the filtration process and the estimation of the initial concentrations are given in Appendix B.

\section{Results and discussion}

\subsection{Simulations}

The effects of the membrane pore radius, $r_{p}$, and the imposed permeate flux, $J_{v}$, on the sieving coefficients, $S_{o b s}$, of the pDNA and 
A

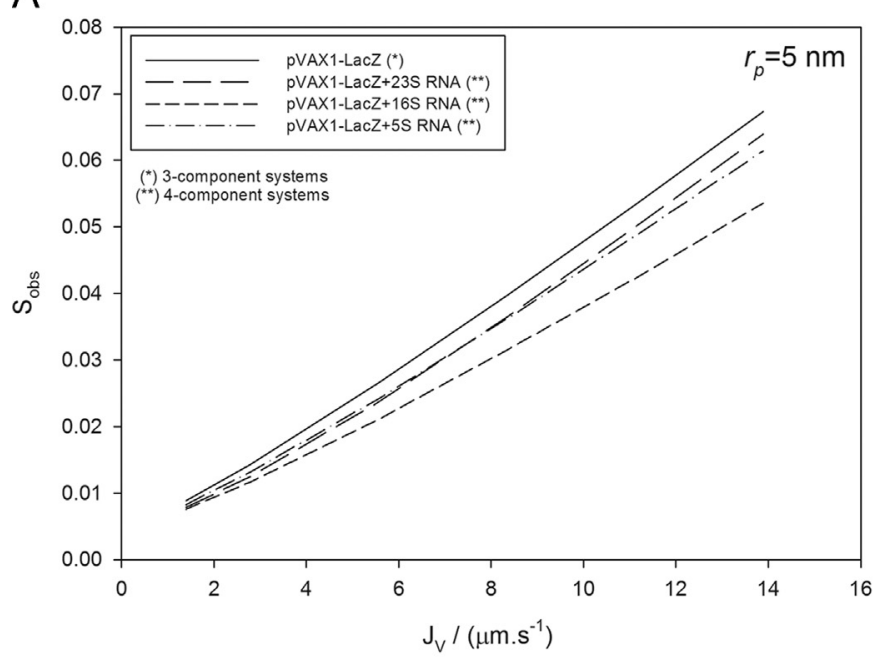

C

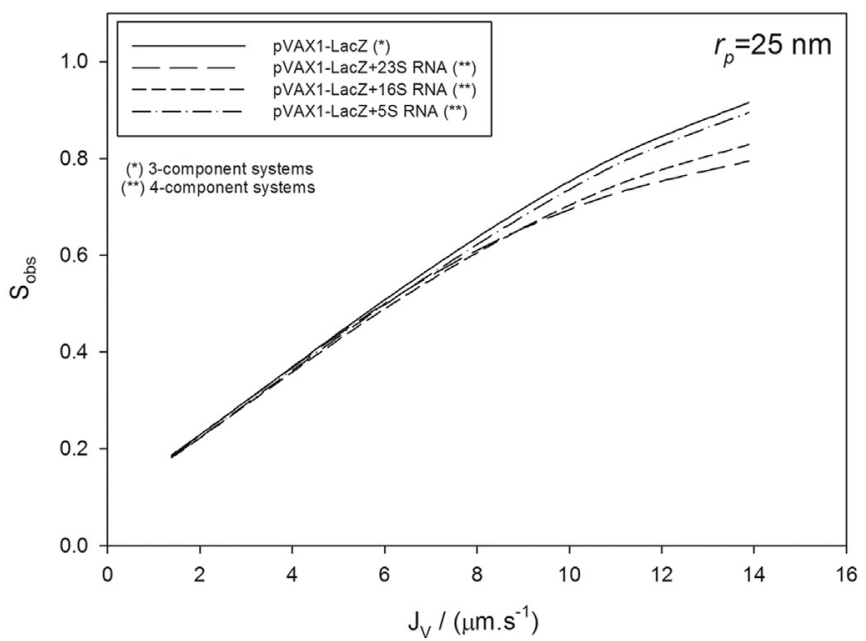

B

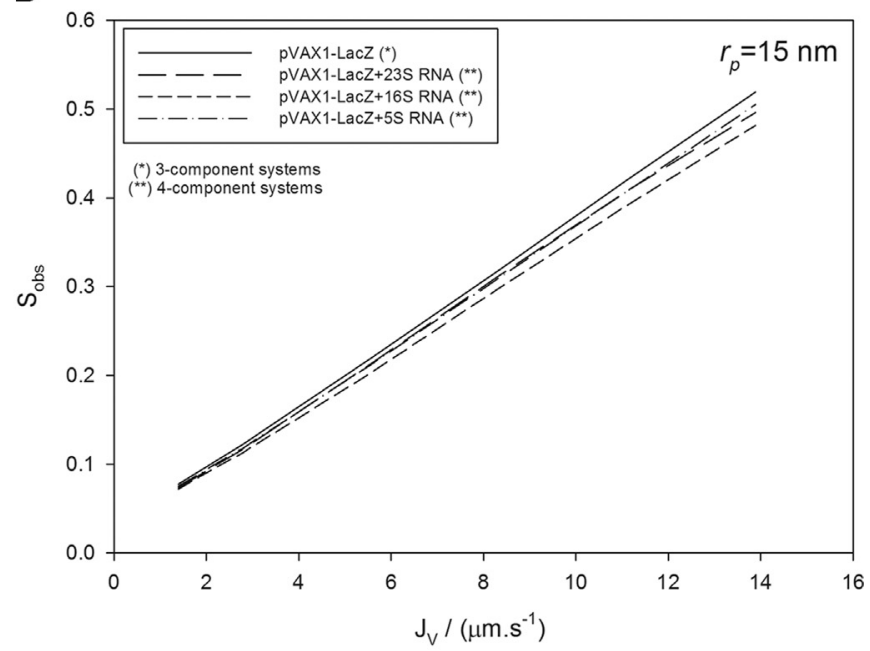

D

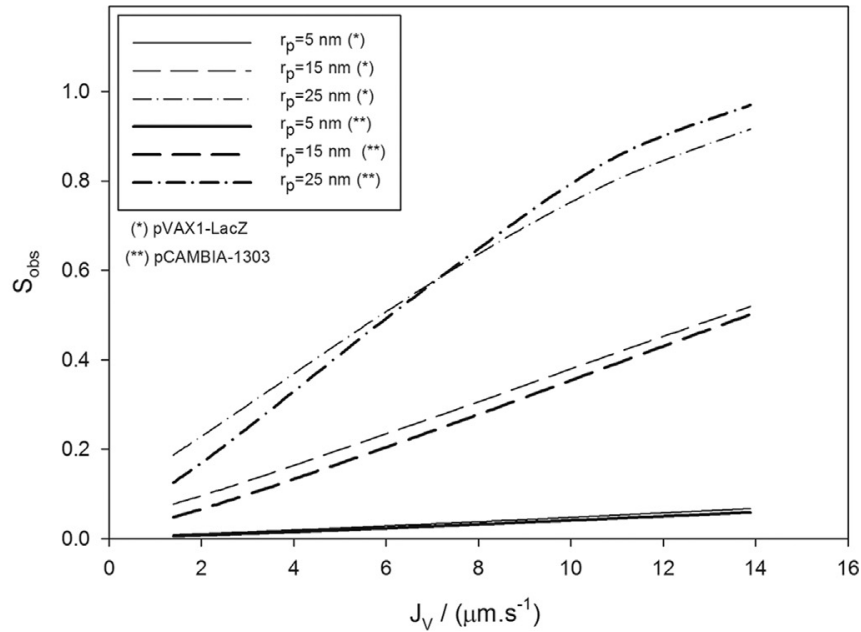

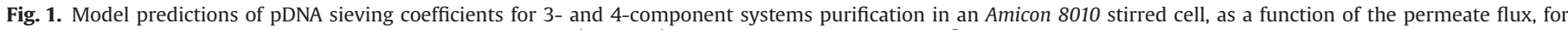

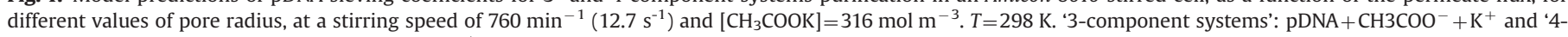
component systems': pDNA $+\mathrm{RNA}+\mathrm{CH}_{3} \mathrm{COO}^{-}+\mathrm{K}^{+}$(as specified in Section 2.5).

RNA molecules indicated in Table 1 were estimated before the experimental part. The predictions were made by numerical simulation, using the 3- and 4-component algorithms described in Section 2.5, and assuming no membrane fouling and no pDNA or RNA adsorption. The possible interactions between pDNA and RNA were investigated using the 4-component algorithm.

As can be seen in Fig. $1 \mathrm{~A}-\mathrm{C}$, the presence of the RNA molecules does not affect, significantly, the sieving coefficients of plasmid pVAX1-LacZ. Similar results were obtained for plasmid pCAMBIA1303 (not shown). However, the presence of pDNA molecules does affect the $S_{o b s}$ values of RNA. As can be seen in Fig. 2, a very significant decrease of the $S_{\text {obs }}$ is predicted, especially at high values of flux and for the high molecular weight RNA species (i.e., 23S and 16S RNA), HMwRNA. The results of these simulations can be interpreted taking into consideration the predicted concentration polarization of each component, herein expressed as $C_{m} / C_{b}$, where $C_{m}$ is the concentration of the component near the membrane surface and $C_{b}$ its concentration in the bulk of the solution. The calculated values of $C_{m} / C_{b}$ for the different macromolecules are shown in Fig. 3 in the case of $r_{p}=5 \mathrm{~nm}$ at $760 \mathrm{rpm}$. As can be seen in the figure, a clearly higher accumulation of pDNA molecules than RNA near the membrane is predicted, which is a consequence of the much lower diffusion coefficients of the pDNA molecules. This accumulation of
pDNA is expected to affect the accumulation of RNA markedly (and probably other negatively charged molecules present in solution, not considered in this study) by decreasing it due to electrostatic repulsion. Accordingly, since a decrease in the concentration of any component near the membrane surface always results in a decrease of the observed sieving coefficients, $S_{o b s}$, the accumulation of pDNA near the membrane is expected to cause a decrease of the $S_{o b s}$ of the RNA species. The effect of RNA molecules on the accumulation of pDNA is clearly smaller than the opposite since RNA molecules are less charged (thus, only for very high concentrations of RNA significant effects would be expected on the concentration polarization of pDNA) and have higher diffusion coefficients. As the diffusion coefficient of a molecule increases, its concentration polarization decreases and therefore its influence on the concentration polarization of other species decreases; for example, one can simulate that, if the diffusion coefficient of plasmid pVAX1-LacZ was, hypothetically, twice the value indicated in Table 1, the RNA $S_{o b s}$ values shown in Fig. 2B would be between 0.32 and 0.58 for $r_{p}=15 \mathrm{~nm}$.

Comparing the two plasmids, it should be noted that not only a similar effect of RNA on the $S_{o b s}$ values was found but also similar $S_{o b s}$ values were obtained, as can be seen in Fig. 1D, although the two plasmids significantly differ in their number of base pairs. The independence of $S_{o b s}$ on the size of the pDNA molecules has 
A

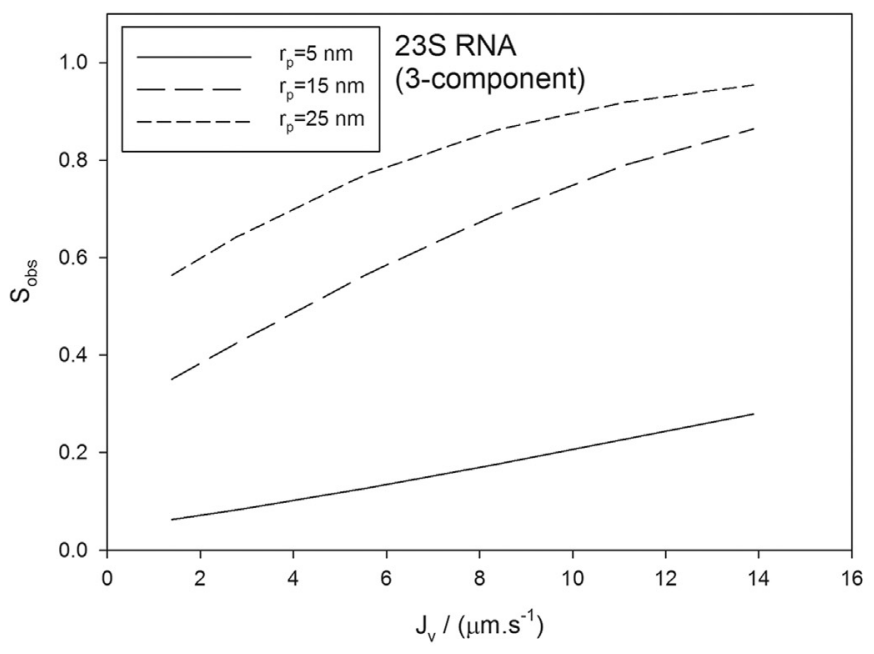

C

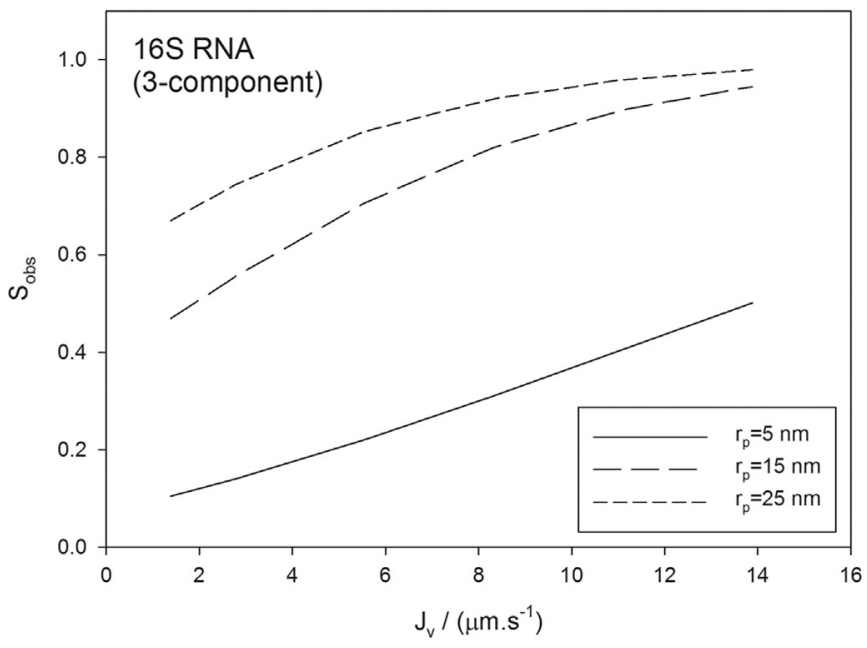

$E$

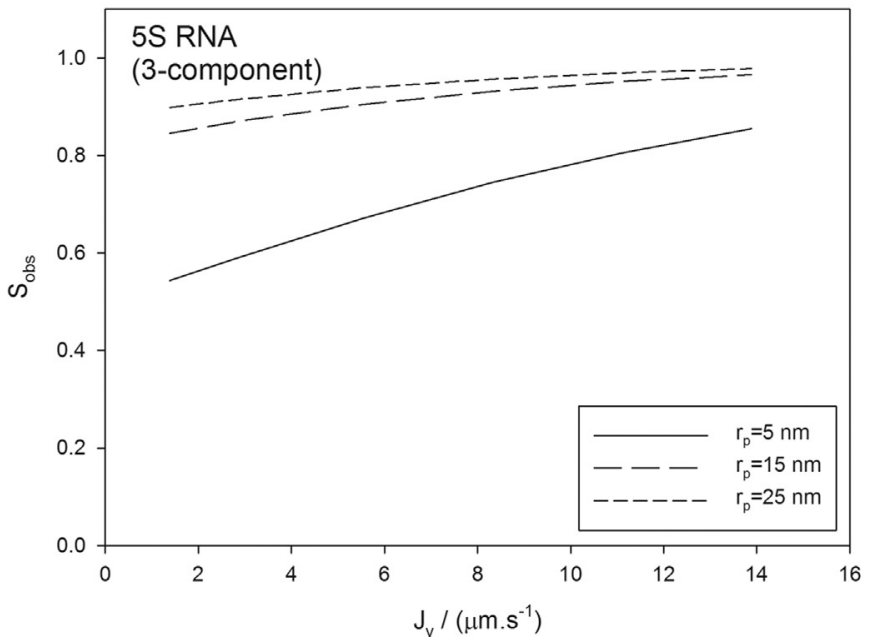

B

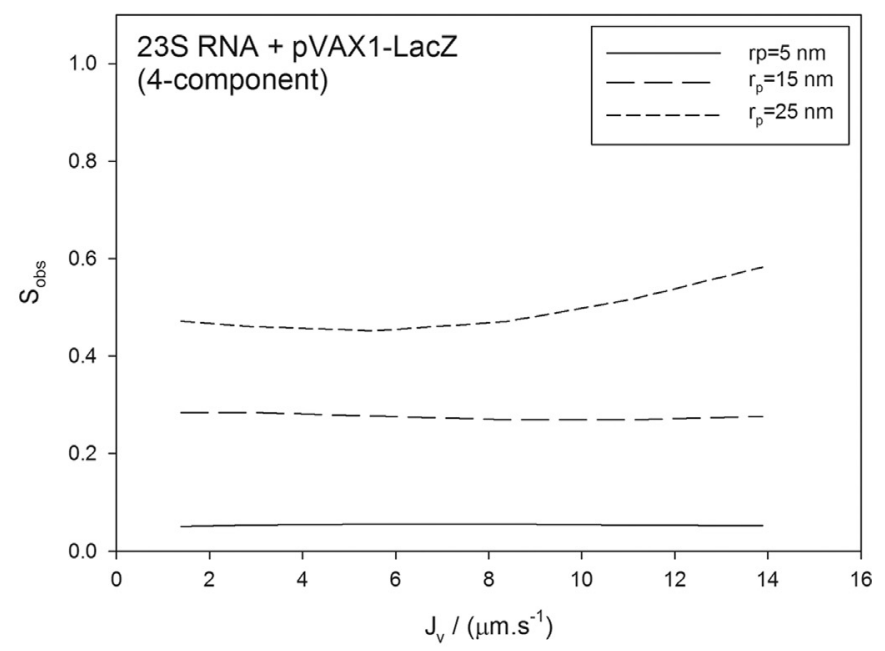

D

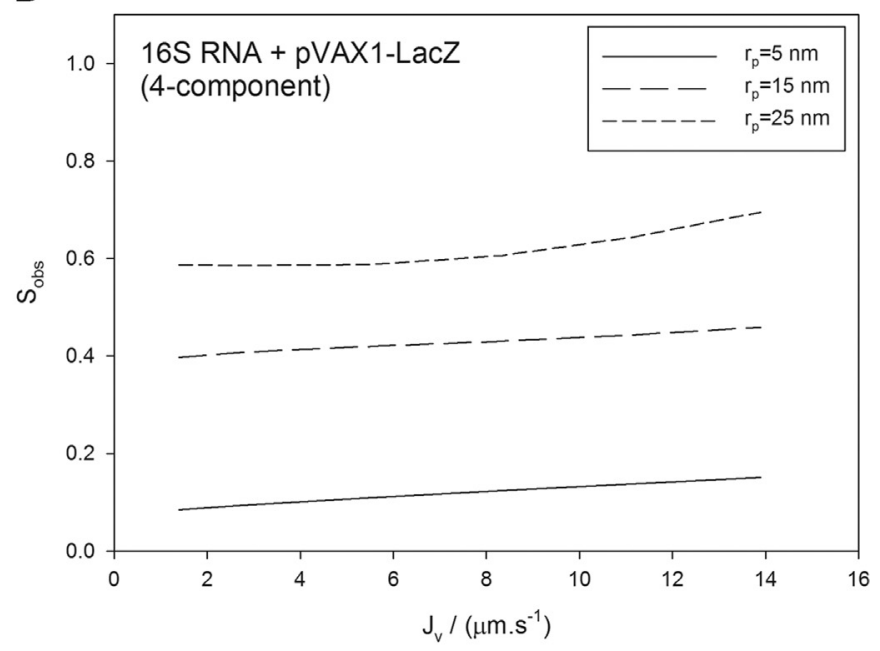

$\mathrm{F}$

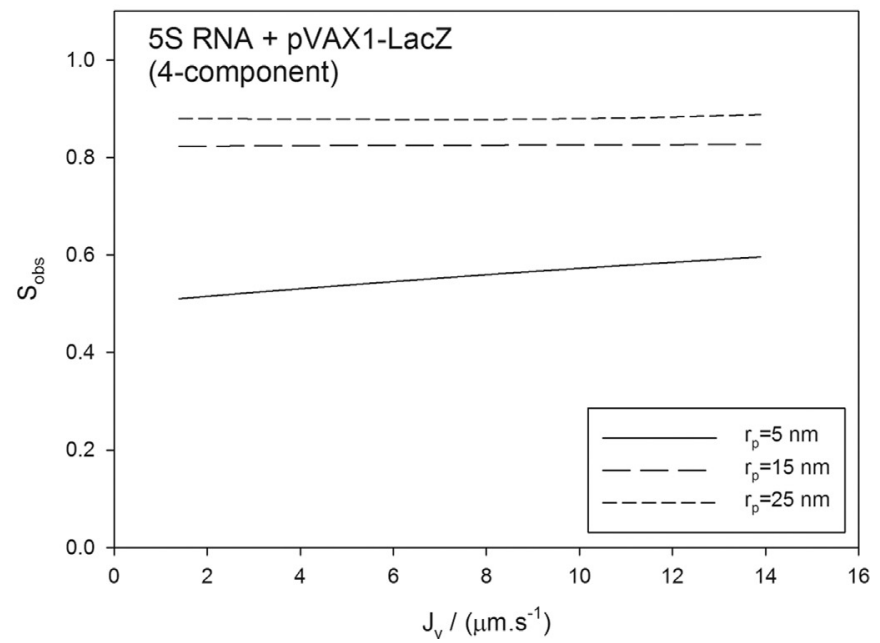

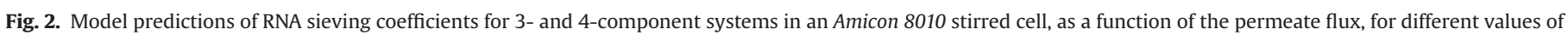

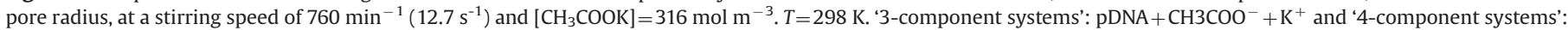
pDNA $+\mathrm{RNA}^{+} \mathrm{CH}_{3} \mathrm{COO}^{-}+\mathrm{K}^{+}$(as specified in Section 2.5).

been reported by other authors [24-26]. According to the model used for the calculations this occurs as a consequence of two opposing effects: the decrease in the probability of permeation of the pDNA molecules as the molecular size increases and the simultaneous decrease in the diffusion coefficients. The first effect leads to lower intrinsic sieving coefficients, $S_{m}$, and the second to higher concentration polarization values; as a consequence, the $S_{o b s}$ values are near insensitive to the pDNA size. 
A

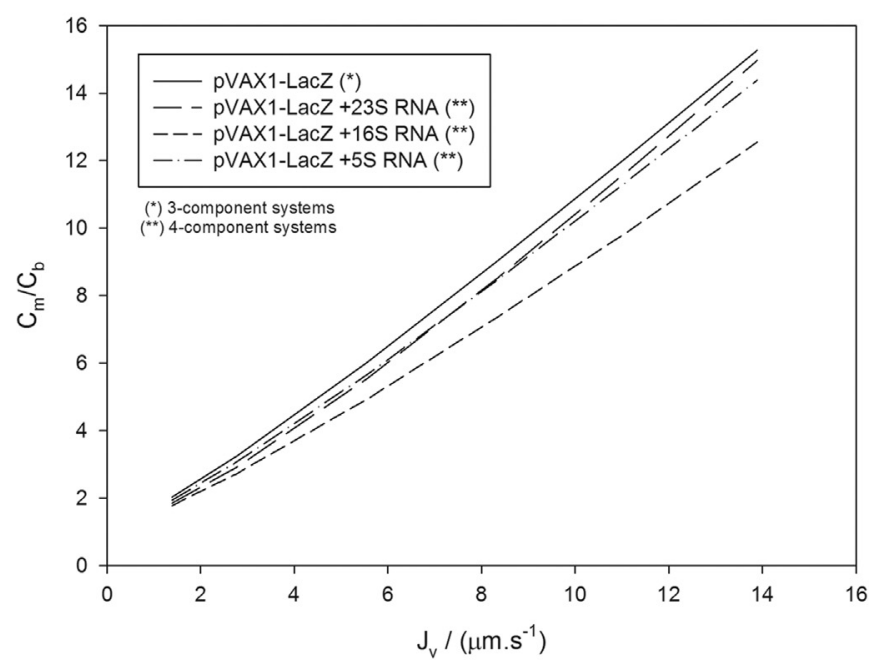

C

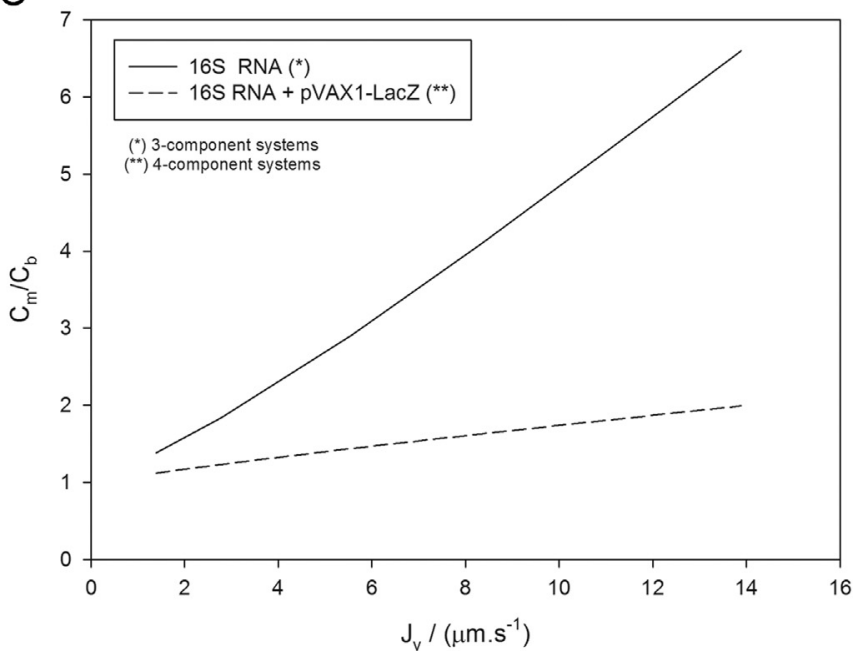

B

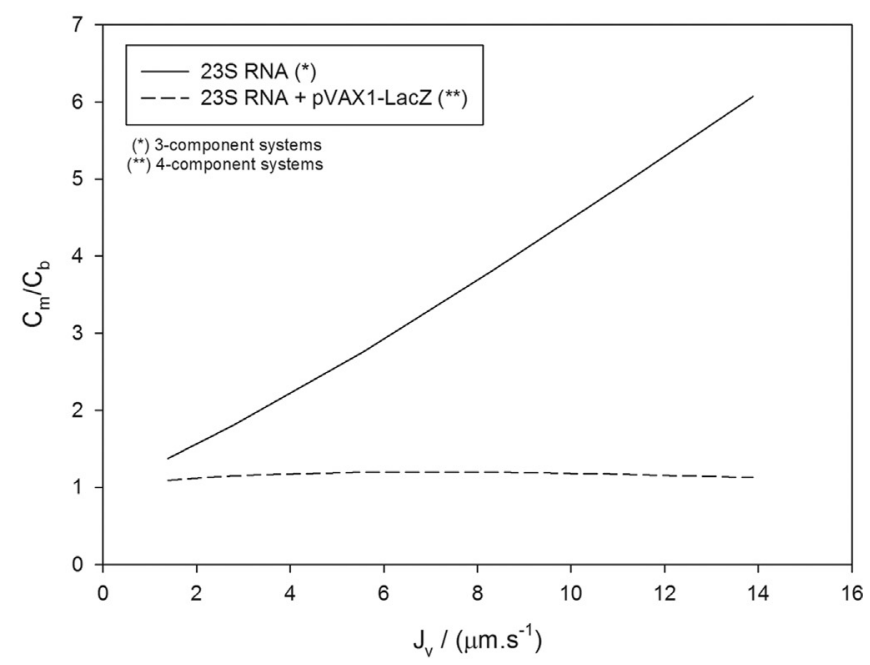

D

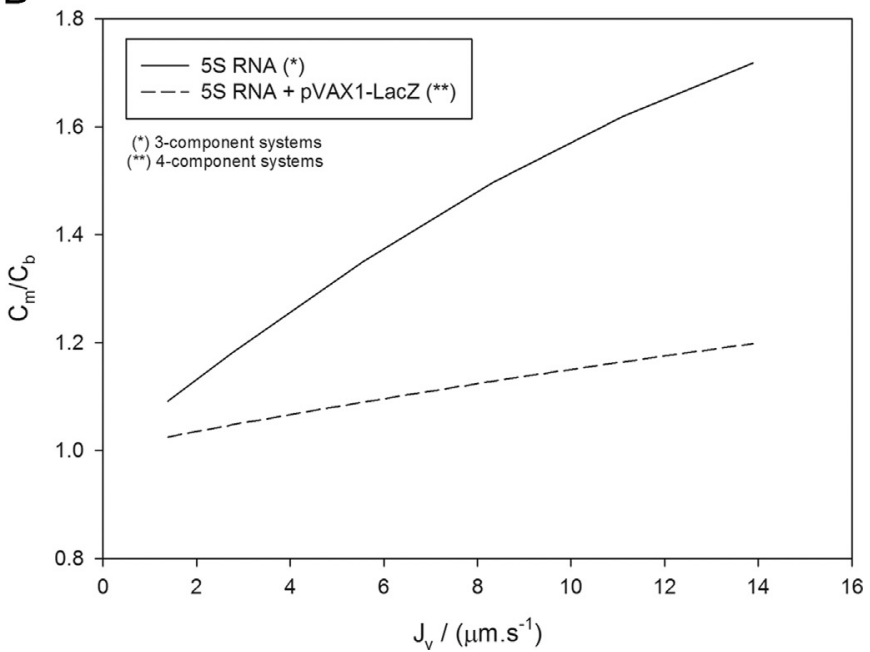

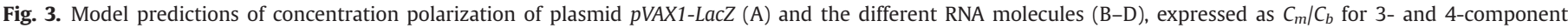

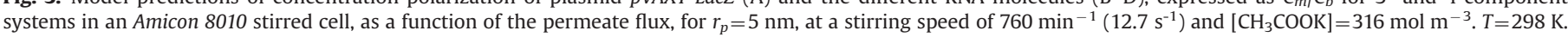
'3-component systems': pDNA $+\mathrm{CH}_{3} \mathrm{COO}^{-}+\mathrm{K}^{+}$and '4-component systems': pDNA + $\mathrm{RNA}+\mathrm{CH}_{3} \mathrm{COO}^{-}+\mathrm{K}^{+}$(as specified in Section 2.5).

About the effects of the pore radius and the imposed permeate flux on the $S_{o b s}$ values, the main conclusion obtained from the simulations is that the $S_{o b s}$ of RNA molecules are almost insensitive to $J_{v}$ due to the presence of the pDNA molecules (see Fig. 2). Thus, in order to obtain a satisfactory purification of pDNA from RNA it becomes clear that one should use membranes of considerably large pores, i.e., $25 \mathrm{~nm}$ or higher, in particular to ensure enough permeation of $H M W R N A$; otherwise, one cannot ensure enough permeation of RNA, even by imposing high values of $J_{v}$. Also, considering that the $S_{o b s}$ of pDNA can be kept low by filtering at low values of flux (1-3 $\mu \mathrm{m} \mathrm{s}^{1}$ ) for $r_{p} \leq 25 \mathrm{~nm}$ (as shown in Fig. 1), one can conclude that the best option in order to separate pDNA from RNA is to perform the ultrafiltration at low $J_{v}$ values using a membrane with $20-25 \mathrm{~nm}$ of pore radius.

\subsection{Experimental results}

In order to check the previous conclusions obtained from the simulations, filtration tests of the microfiltered lysates from pVAX1-LaCZ and pCAMBIA-1303 production were performed using two different ultrafiltration membranes, one with $\mathrm{r}_{p}=4.8 \mathrm{~nm}$ [21] and the other with $r_{p}=25 \mathrm{~nm}$, respectively, the $100 \mathrm{kDa}$ and
$300 \mathrm{kDa}$ of MWCO membranes mentioned in Section 2.3. The value of $r_{p}=25 \mathrm{~nm}$ was experimentally determined using the SPM method described in [21] from observed sieving coefficients of dextrans T70 and T500. Two different stirring speeds were tested (100 and $760 \mathrm{~min}^{-1}$ ) and different values of flux in the range of $1.4-8.3 \mu \mathrm{m} \mathrm{s}^{-1}\left(5-30 \mathrm{~L} \mathrm{~h}^{-1} \mathrm{~m}^{-2}\right)$.

The results of the filtration tests (concentration to $V C F=10$ ) are shown in Fig. 4. The filtration yield, in each test, was calculated as the ratio of the amount of pDNA in the ultrafiltration concentrate to the amount of pDNA in the microfiltration permeate (MFP). The RNA removal was calculated as $1-\left(V_{p} C_{R N A, p}\right) /\left(V_{M F P} C_{R N A, M F P}\right)$ where $C_{R N A, p}$ is the RNA concentration in the whole collected ultrafiltration permeate and $C_{R N A, M F P}$ is the RNA concentration in the MFP, $V_{p}$ is the volume of permeate collected and $V_{M F P}$ is the volume of MFP processed in each run.

As can be seen, the use of the membrane with $r_{p}=25 \mathrm{~nm}$, working at low values of flux, is clearly a better option to simultaneously achieve a high pDNA yield and a high RNA removal. In fact, the RNA removal is very low for the membrane with $r_{p}=4.8 \mathrm{~nm}$ of radius and, on the contrary, for the membrane with $r_{p}=25 \mathrm{~nm}$ high RNA removal is observed in the whole range of permeate flux considered in the experiments; however, in the 
A

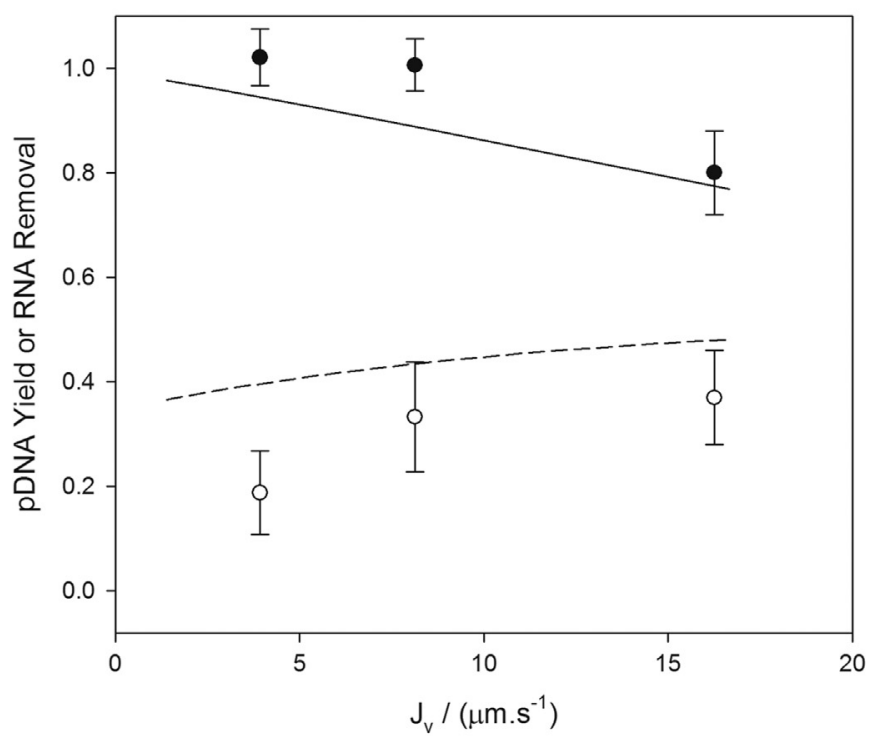

C

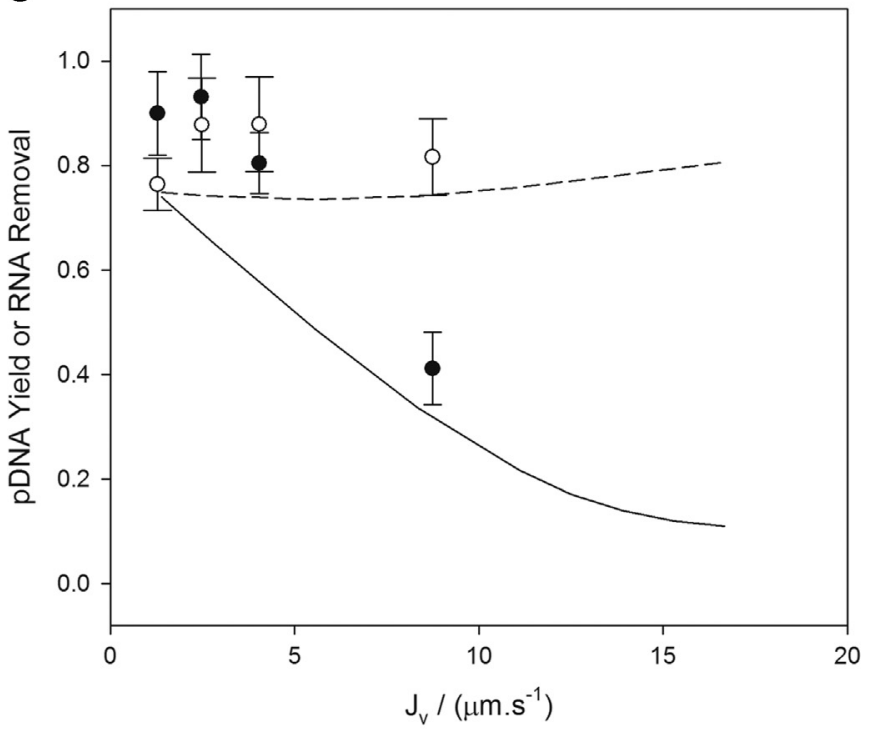

B

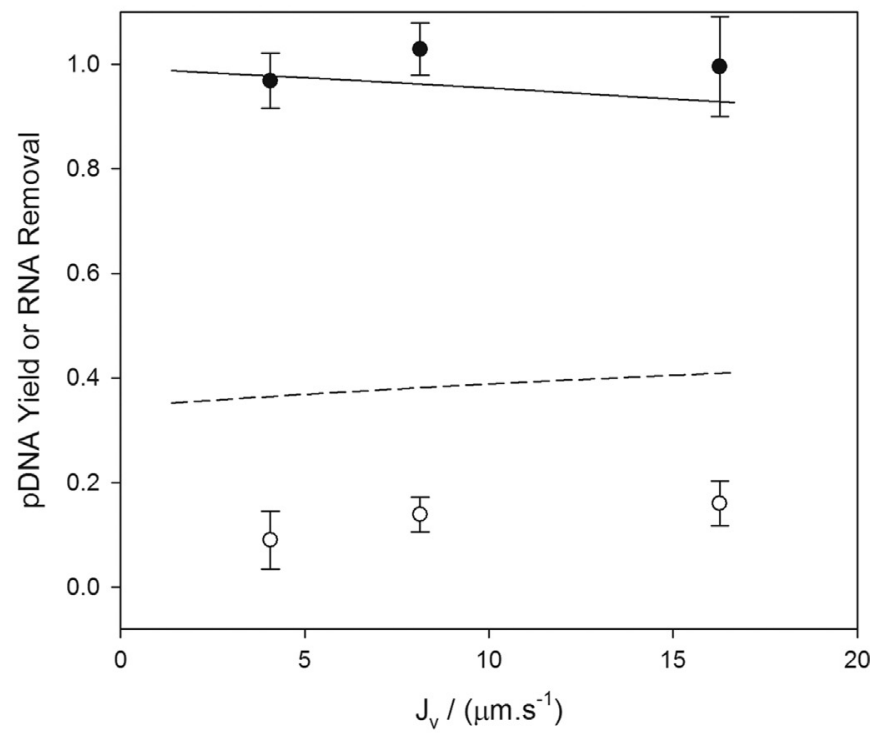

$\mathrm{D}$

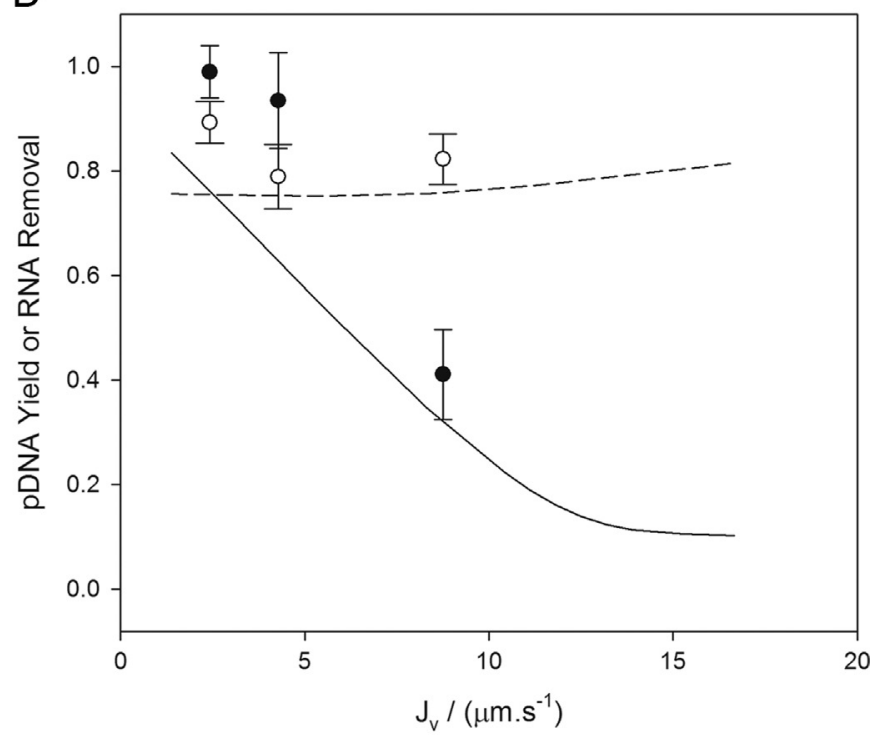

$$
\begin{aligned}
& p D N A \text { Yield (exp) } \\
- & p D N A \text { Yield (T) } \\
\hline & \text { Total RNA Removal (exp) } \\
--- & \text { Total RNA Removal (T) }
\end{aligned}
$$

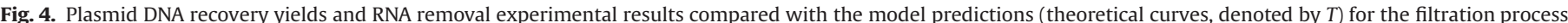

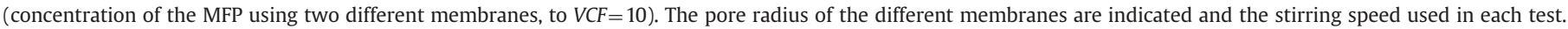

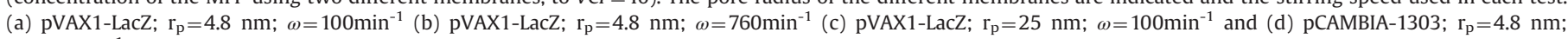
$\omega=100 \mathrm{~min}^{-1}$.

case of the $25 \mathrm{~nm}$ membrane, only for low values of flux the pDNA recovery yield is simultaneously high.

To compare these experimental results with the model predictions, calculations of the pDNA recovery yield and RNA removal were made, respectively, using the 3-component algorithm (since the presence of RNA molecules only slightly affects the permeation of pDNA, as previously seen) and the 4-component algorithm (to consider the effect of the presence of pDNA on the permeation of each type of RNA molecules).

The predictions of total RNA removal, indicated in Fig. 4, were obtained from the initial concentrations of each type of RNA (indicated in Table 1) and the estimated removal of the different RNA species that are indicated in Fig. 5. As can be seen in Fig. 4, both the predictions of permeation yield and total RNA removal agree well with the experimental results, although a small tendency toward higher pDNA recovery yields and lower RNA removal values than predicted is observed. This tendency indicates that the real $S_{o b s}$ of both pDNA and RNA molecules were slightly lower than the predicted, which could be possibly due to the occurrence of some pDNA adsorption, a phenomenon which has been previously reported to occur, to a variable extent, in different types of membranes [3].

The success of the application of the ultrafiltration technique for separating pDNA from RNA with the $25 \mathrm{~nm}$ membrane was also checked by electrophoresis (see Fig. 6), besides the HPLC assay. The HPLC assay used in this work can be used to determine the total 
A

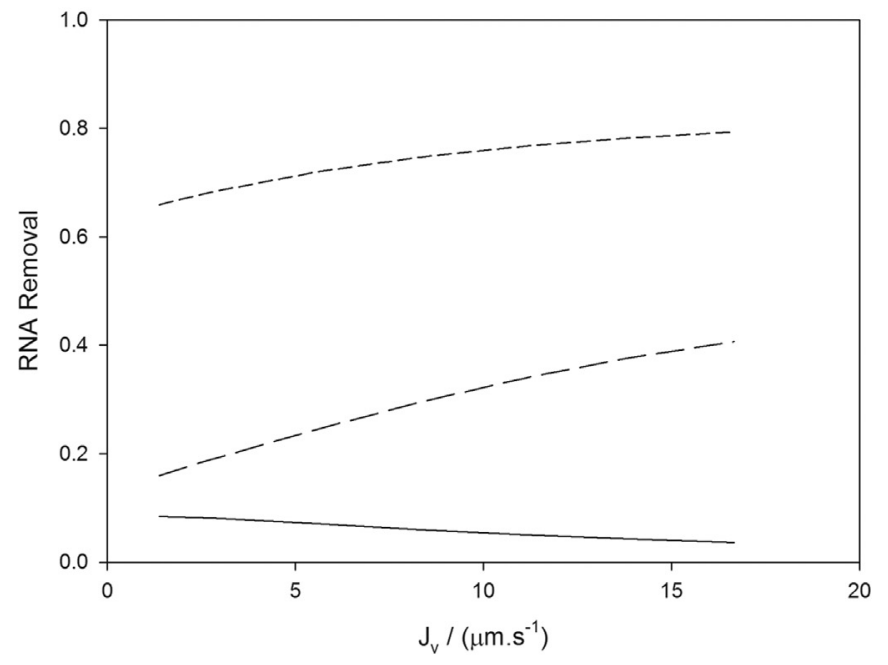

C

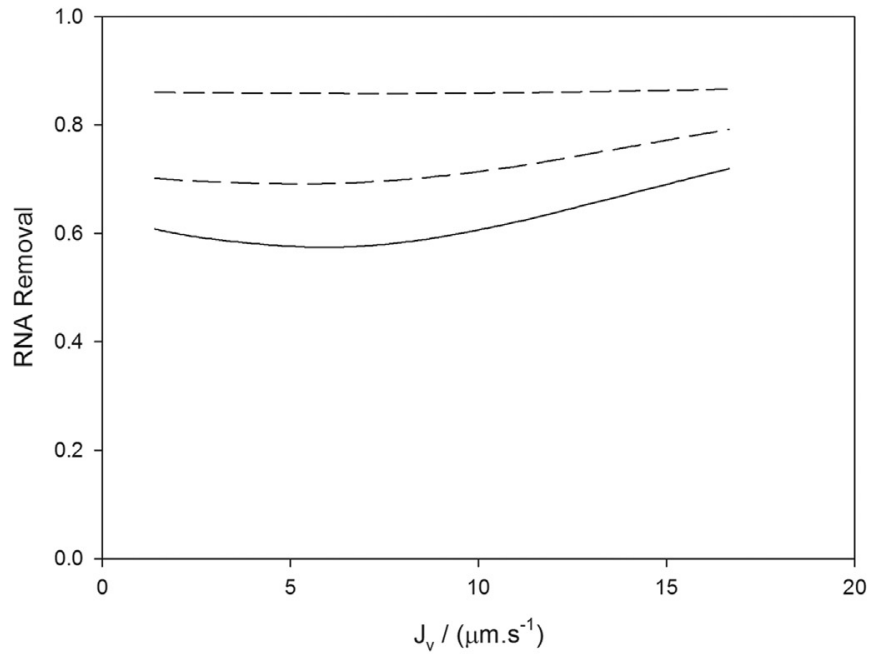

B

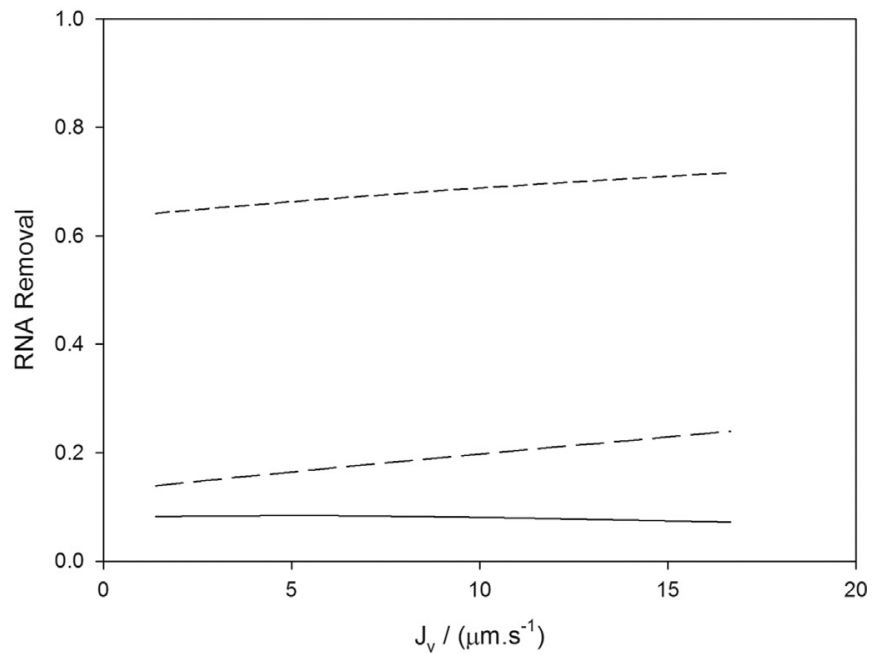

D

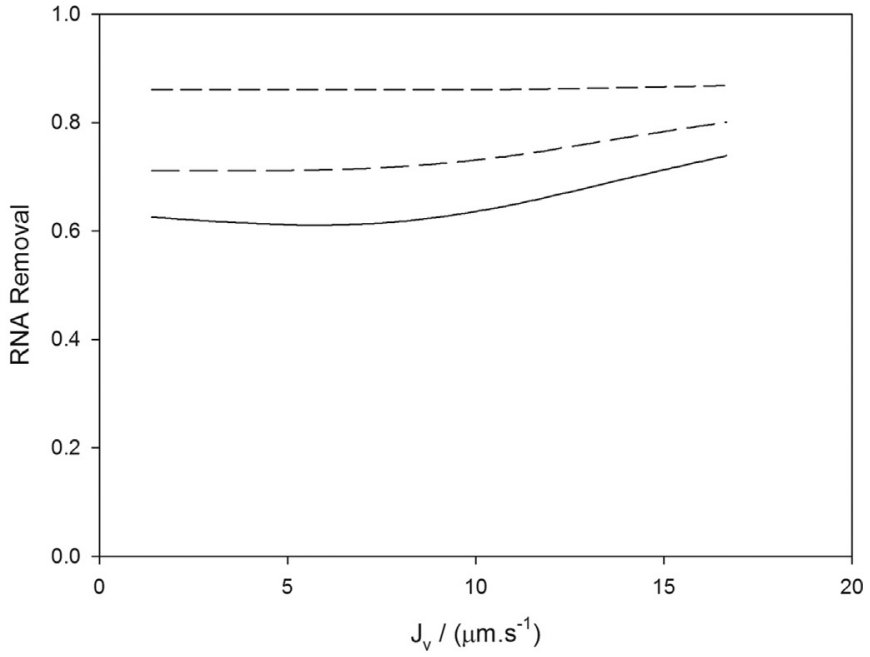

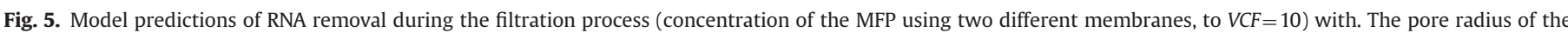

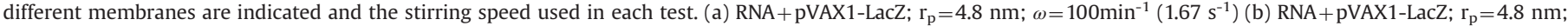
$\omega=760 \mathrm{~min}^{-1}\left(12.7 \mathrm{~s}^{-1}\right)$ (c) RNA + pVAX1-LacZ; $\mathrm{r}_{\mathrm{p}}=25 \mathrm{~nm} ; \omega=760 \mathrm{~min}^{-1}\left(12.7 \mathrm{~s}^{-1}\right)$ and (d) RNA + pVAX1-LacZ; $\mathrm{r}_{\mathrm{p}}=25 \mathrm{~nm} ; \omega=760 \mathrm{~min}^{-1}\left(12.7 \mathrm{~s}^{-1}\right)$.

amount of RNA, however, it cannot separately quantify the different forms of RNA. Thus, we use agarose gel electrophoresis to compare the permeation behavior of different sizes of RNA. As can be seen in the figure, using the $25 \mathrm{~nm}$ membrane (Biomax 300) the ultrafiltration permeates (UFP) contain RNA but do not contain pDNA(sc). Moreover, permeation of HMwRNA is clearly observed indicating that the purification of pDNA from both HMwRNA and LMwRNA can be achieved. In contrast, in the ultrafiltrations performed with the $4.8 \mathrm{~nm}$ membrane (FS4OPP) almost all the RNA is retained by the membrane, especially HMwRNA, in agreement with the theoretical predictions.

\section{Conclusions}

Separation of pDNA from both HMwRNA and LMwRNA can be achieved by ultrafiltration. An optimization of the membrane pore size and permeate flux is essential to achieve this goal. The ability of predicting the sieving coefficients of both pDNA and RNA, with good accuracy, is decisive in this process. According to the 4component model developed here strong interactions between pDNA and RNA occur in the concentration polarization layer during filtration which have a profound effect on the sieving coefficients of the RNA molecules. Essentially, the model predicts that the pDNA molecules can exclude the RNA molecules from the membrane surface due to their higher electrical charge and lower diffusion coefficients, although being present at relatively low concentrations; this effect strongly decreases the sieving coefficients of the RNA molecules.

The experimental results confirm the predictions of the model in terms of membrane selectivity, namely, in showing that a membrane with a pore radius of $25 \mathrm{~nm}$ operated at low values of flux is near the best option to purify the pDNA (tests with two different plasmids confirm the idea). A further optimization of the separation of pDNA from RNA is expected to be achieved using a 20-25 nm membrane and by performing a diafiltration upon 


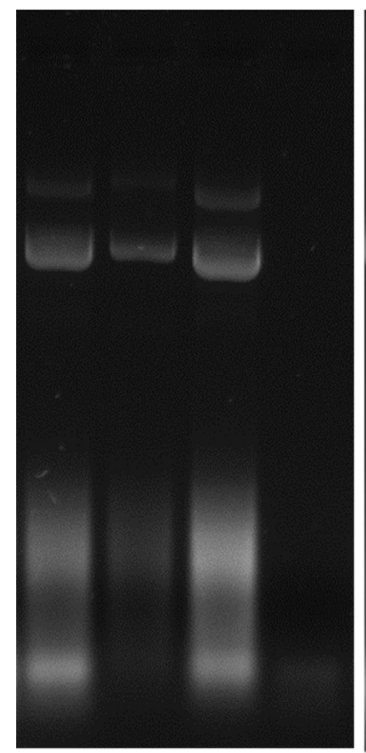

$1 \quad 2 \quad 3 \quad 4$

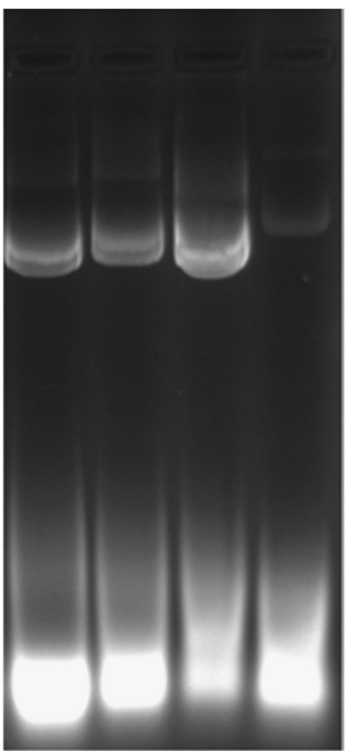

$\begin{array}{llll}5 & 6 & 7 & 8\end{array}$

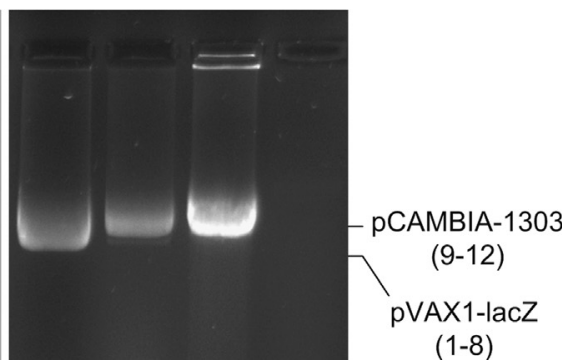

$(1-8)$

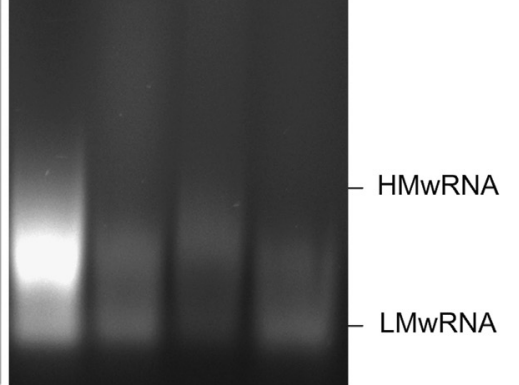

$9 \quad 10 \quad 11 \quad 12$

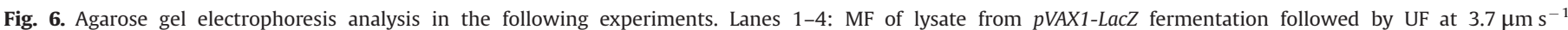

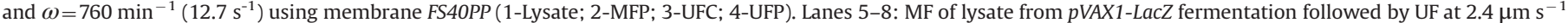

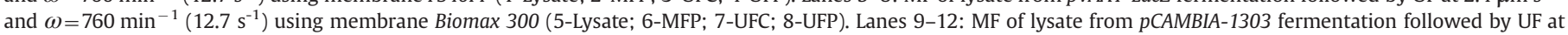
$2.4 \mu \mathrm{m} \mathrm{s}^{-1}$ and $\omega=760 \mathrm{~min}^{-1}\left(12.7 \mathrm{~s}^{-1}\right)$ using membrane Biomax 300 (9-Lysate; 10-MFP; 11-UFC; 12-UFP).

concentration of the solution. This will be the object of study in the near future.

\section{Acknowledgments}

Fundação para a Ciência e a Tecnologia (FCT), Portugal, for the financial support (PTDC/EBB-BIO/114320/2009) and the grants awarded to António Morão (SFRH/BPD/88838/2012) and José Carlos Nunes (SFRH/BD/48801/2008). Financial support from project FCOMP-Ol-0124-FEDER-014757 - FCT is also gratefully acknowledged.

\section{Appendix A}

The numerical method was adapted as follows. The first step of the proposed algorithm is guessing the concentration of the 4 species in solution near the membrane (that differ from the bulk solutions due to concentration polarization). These are denoted, as previously [3], by $C_{m, i}$. Since 4 species are considered, one needs to guess $C_{m, 1}^{0}, C_{m, 2}^{0}$ and $C_{m, 3}^{0}$, where ' 1 ' denotes the plasmid, ' 2 ' the RNA and ' 3 ' the acetate ion; then, from a charge balance, the concentration of the fourth component, $C_{m, 4}^{0}$, where ' 4 ' denotes the potassium ion, can be calculated. Following an analogy with the 3-component algorithm (see Appendix A of [3]), the concentration of the species in the permeate, $C_{p, i}$, are then estimated as $\Phi_{i} C_{m, i}^{0}$ for the macromolecules and as $C_{m, 3}^{0}$ for the acetate ion (assuming no retention of this ion due to steric effects); $C_{p, 4}$ is calculated by a charge balance. With the $C_{p, i}$ values, the set of differential equations (3) specified in [3] can be solved along the concentration polarization layer, simultaneously with the set of equations (4) specified in the same reference, using the bulk concentrations of the species, $C_{b, i}$, as initial conditions to obtain a new guess for the $C_{m, i}$ values, that will be denoted as $C_{m, i}^{1}$; these values can be compared with the previously guessed $C_{m, i}^{0}$. The following error function was used to compare the two sets of values:

$f\left(C_{m, i}^{0}, C_{m, i}^{1}\right)=\sum_{i=1}^{4} \frac{\left|C_{m, i}^{0}-C_{m, i}^{1}\right|}{C_{b, i}}$

In order to obtain the correct set of $C_{m, i}$ values, the initially guessed values of $C_{m, i}$ can be varied along pre-established intervals, to find the minimum value of $f$.

\section{Appendix B}

The continuous batch process was approached to a series of discrete filtration steps (90 steps were considered, each one corresponding to $\Delta V_{p}=0.1 \mathrm{ml}$ of collected permeate). Since the concentration of a macromolecule affects its own sieving coefficient, and the concentrations of the macromolecules were expected to significantly change along the filtration process, in each filtration step, $n$, a sieving coefficient value, $S_{o b s, n}$, was determined for the macromolecule under consideration (pDNA or RNA species) by considering the initial concentration of that macromolecule in each step. $S_{o b s, n}$ values were estimated as described in Section 2.5. Then, assuming that the concentration in the collected permeate in each step, $n$, approaches $S_{o b s, n} C_{0, n}$, where $C_{0, n}$ is the initial concentration of the macromolecule in each step, it follows that the initial concentration to consider for the next step will be $C_{0, n+1} \approx\left(C_{0, n} V_{0, n}-S_{o b s, n} C_{0, n} \Delta V_{p}\right) /\left(V_{0}\right.$, $\left.n-n \Delta V_{p}\right)$. This expression was used throughout the concentration process, i.e., from $n=1$ to 90 . From each $C_{0, n+1}$, a new value for the sieving coefficient, $S_{o b s, n+1}$ was calculated, allowing the estimation of the retained and permeated amounts of the macromolecule in each step and, therefore, the quantities in the whole permeate and final retentate. Total permeation of the $\mathrm{CH}_{3} \mathrm{COO}^{-}$ion was always assumed (thus, its concentration remained constant throughout the filtration process).

The concentration of pDNA in the microfiltration permeates was determined by HPLC (Section 2.4.1). The concentration of the different RNA species was estimated using the following approach. The total RNA mass concentration in microfiltration permeates was calculated from the HPLC band corresponding to hydrophobic 
components, according to the conclusions of a previous study [8]. Then, from the total RNA mass concentration and the relative intensities of the bands corresponding to high molecular weight RNA (HMwRNA) and low molecular weight RNA (LMwRNA) in electrophoretograms of the microfiltration permeates, the mass concentration of both HMwRNA and LMwRNA were estimated. Finally, assuming that all the LMwRNA is 5S RNA and that half of the HMwRNA is 23S RNA and the other half is 16S RNA, the mass concentrations of each type of RNA were approximately estimated. The corresponding molar concentrations, calculated with the Mw of each type of RNA, are given in Table 1 .

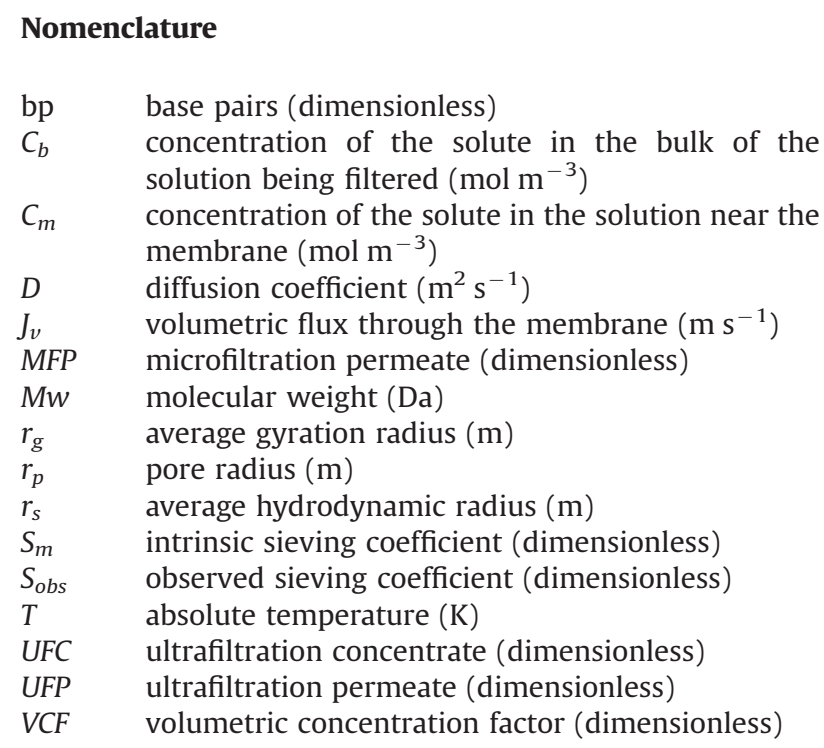

Greek symbols

$\omega \quad$ angular velocity $\left(\mathrm{s}^{-1}\right)$

\section{References}

[1] K.J. Prather, S. Sagar, J. Murphy, M. Chartrain, Industrial scale production of plasmid DNA for vaccine and gene therapy: plasmid design, production, and purification, Enzyme Microb. Technol. 33 (2003) 865-883.

[2] J.A. Williams, A.E. Carnes, Plasmid DNA manufacturing technology, Recent Pat. Biotechnol. 1 (2007) 1-15.

[3] A.M. Morão, J.C. Nunes, F. Sousa, M.T.P. de Amorim, I.C. Escobar, J.A. Queiroz, Ultrafiltration of supercoiled plasmid DNA: modeling and application, J. Membr. Sci. 378 (2011) 280-289.

[4] A.S. Rathore, A. Shirke, Recent developments in membrane-based separations in biotechnology processes: review, Prep. Biochem. Biotechnol. 41 (2011) 398-421.
[5] Z.A. Reis, R. Bioprocess, Membrane technology, J. Membr. Sci. 297 (2007) $16-50$

[6] F. Sousa, et al., Selective purification of supercoiled plasmid DNA from clarified cell lysates with a single histidine-agarose chromatography step, Biotechnol. Appl. Biochem. 45 (3) (2006) 131-140.

[7] A. Eon-Duval, R.H. MacDuff, C.A. Fisher, M.J. Harris, C. Brook, Removal of RNA impurities by tangential flow filtration in an RNase-free plasmid DNA purification process, Anal. Biochem. 316 (2003) 66-73.

[8] J.C. Nunes, A.M. Morão, C. Nunes, M.T.P. de Amorim, I.C. Escobar, J.A. Queiroz, Plasmid DNA recovery from fermentation broths by a combined process of micro- and ultrafiltration: modeling and application, J. Membr. Sci. 415-416 (2012) 24-35

[9] S. Freitas, S. Canário, J.A.L. Santos, D.M.F. Prazeres, Alternatives for the intermediate recovery of plasmid DNA: Performance, economic viability and environmental impact, Biotechnol. J. 4 (2009) 265-278.

[10] B Riesmeier, K Kroner, M. Kula, Tangential filtration of microbial, suspensions: filtration resistances and model development, J. Biotechnol. 12 (1989) $153-172$.

[11] A. Morão, A.M. Brites Alves, J.P. Cardoso, Ultrafiltration of demethylchlortetracycline industrial fermentation broths, Sep. Purif. Technol. 22-23 (2001) 459-466.

[12] A.M. Brites Alves, A. Morão, J.P. Cardoso, Isolation of antibiotics from industrial fermentation broths using membrane technology, Desalination 148 (2002) $181-186$.

[13] S. Kong, N. Titchener-Hooker, M.S. Levy, Plasmid DNA processing for gene therapy and vaccination: studies on the membrane sterilisation filtration step, J. Membr. Sci. 280 (2006) 824-831.

[14] S. Kong, J. Aucamp, N.J. Titchener-Hooker, Studies on membrane sterile filtration of plasmid DNA using an automated multiwell technique, J. Membr. Sci. 353 (2010) 144-150.

[15] D. Kendall, G.J. Lye, M.S. Levy, Purification of plasmid DNA by an integrated operation comprising tangential flow filtration and nitrocellulose adsorption, Biotechnol. Bioeng. 79 (2002) 816-822.

[16] A. Eon-Duval, K. Gumbs, C. Ellett, Precipitation of RNA impurities with high salt in a plasmid DNA purification process: use of experimental design to determine reaction conditions, Biotechnol. Bioeng. 83 (2003) 544-553.

[17] D.W. Kahn, Purification of plasmid DNA by tangential flow filtration, Abstr Pap. Am. Chem. Soc. 224 (2002) U223 (U223).

[18] A. Morão, J.C. Nunes, F. Sousa, M.T. Pessoa de Amorim, I.C. Escobar, J.A. Queiroz, Development of a model for membrane filtration of long and flexible macromolecules: application to predict dextran and linear DNA rejections in micro and ultrafiltration, J. Membr. Sci. 336 (2009) 61-70.

[19] A. Sousa, C.T. Tomaz, F. Sousa, J.A. Queiroz, Successful application of monolithic innovative technology using a carbonyldiimidazole disk to purify supercoiled plasmid DNA suitable for pharmaceutical applications, J. Chromatogr. A 1218 (2011) 8333-8343.

[20] H.C. Birnboim, J. Doly, Rapid alkaline extraction procedure for screening recombinant plasmid DNA, Nucl. Acids Res. 7 (6) (1979) 1513-1523.

[21] A. Morão, M.T. Pessoa de Amorim, A. Lopes, I. Escobar, J.A. Queiroz, Characterisation of ultrafiltration and nanofiltration membranes from rejections of neutral reference solutes using a model of asymmetric pores, J. Membr. Sci. 319 (2008) 64-75.

[22] M.M. Diogo, J.A. Queiroz, D.M.F. Prazeres, Assessment of purity and quantification of plasmid DNA in process solutions using high-performance hydrophobic interaction chromatography, J. Chromatogr. A 998 (1-2) (2003) 109-117.

[23] D.M.F. Prazeres, Prediction of diffusion coefficients of plasmids, Biotechnol. Bioeng. 99 (2008) 1040-1044.

[24] D.R. Latulippe, K. Ager, A.L. Zydney, Flux-dependent transmission of supercoiled plasmid DNA through ultrafiltration membranes, J. Membr. Sci. 294 (2007) 169-177.

[25] D.R. Latulippe, A.L. Zydney, Salt-induced changes in plasmid dna transmission through ultrafiltration membranes, Biotechnol. Bioeng. 99 (2008) 390-398.

[26] D.R. Latulippe, A.L. Zydney, Elongational flow model for transmission of supercoiled plasmid DNA during membrane ultrafiltration, J. Membr. Sci. 329 (2009) 201-208. 